Anselmo Peres Alós

Universidade Federal do Rio Grande do Sul

\title{
Não contar a ninguém ou contar a todo mundo? Colapsos da masculinidade em No se lo digas a nadie
}

Resumo: Tomando-se como pressupostos teóricos a narratologia e os queer studies, realiza-se aqui uma leitura crítica de No se lo digas a nadie (Não conte a ninguém), romance do peruano Jaime Bayly, publicado pela primeira vez em 1994, no qual se questiona o regime heteronormativo sob o qual opera a sociedade peruana. Investe-se, para tanto, no potencial subversivo de um lugar de enunciação literária marcado pela diferença e pela resistência aos dispositivos de regulação das identidades sexuais.

Palavras-chave: literatura comparada; romance peruano; No se lo digas a nadie; Jaime Bayly.

Copyright (c) 2013 by Revista Estudos Feministas.

\footnotetext{
1 Jaime BAYLY, 2003, p. 141. Todas as traduções das citações das obras em língua estrangeira apresentadas neste artigo são de minha responsabilidade.
}

${ }^{2}$ Martín PAREDES e Ricardo ZAVALETA, 2002, p. 2

\begin{abstract}
"Neste país há certas coisas das quais não se deve falar, e nossa debilidade pelos homens é uma dessas coisas. Eu prefiro ficar tranquilito no armário. Se crês que a tua missão é imolar-te pela causa de umas bichinhas e de uns travestis [...] te dou minhas felicitações, tiro o chapéu e te desejo toda a sorte do mundo, mas não me peças que salte contigo ao precipício. Alfonso, personagem de No se lo digas a nadie.'
\end{abstract}

"O que é Jaime Bayly? Um escritor, antes de tudo, ainda que muitos o neguem: Jaime Bayly, como sabemos, está entregue à mercadotecnia e ao escândalo e, de nenhum modo, à literatura". ${ }^{2}$ Se é verdade que outros escritores latinoamericanos, tais como Manuel Puig e Caio Fernando Abreu, extraíram da cultura de massas e dos meios de comunicação de largo alcance (como o rádio e o cinema) o sumo para suas poéticas autorais, também é verdade que o peruano Jaime Bayly é um dos escritores de seu país que mantêm a relação mais estreita (e, por que não afirmar, mais profícua) com o mundo midiático e com os meios de comunicação. 
${ }^{3}$ Romances: No se lo digas a nadie (1994); Fue ayer y no me acuerdo (1995); Los últimos días de 'La Prensa' (1996); La noche es virgen (1999); Los amigos que perdí (2000); Aquí no hay poesía (2001): La mujer de mi hermano (2002); EI huracán lleva tu nombre (2004); $Y$ de repente, un ángel (2005); EI canalla sentimental (2008); El cojo y el loco (2009); Morirás mañana (2010); El misterio de Alma Rossi: morrirás mañana II (2011); Escupiran sobre mi tumba: morirás manana III (2012). No se lo digas a nadie e La mujer de mi hermano foram adaptados para o cinema. ${ }^{4}$ Gérard Genette ([s.d.]], em seus estudos sobre a estrutura do discurso narrativo, caracteriza o narrador em três modalidades: 0 narrador heterodiegético (isto é, aquele que se localiza completamente fora do universo ficcional da narrativa e que conta a história com recurso à onipresença, d̀ onividência e à onisciência, como um pequeno demiurgo a criar um mundo simultaneamente ao ato de narrar); o narrador homodiegético (ou seja, aquele que participa da história que está contando, via de regra como um personagem de segunda ou terceira mão, $e$ que testemunhou os eventos que está relatando) e, finalmente, onarrador autodiegético (vale dizer, aquele que, ademais de ter testemunhado a história que está contando, figura como protagonista principal da narrativa. Ele pode ser relacionado ao discurso autobiográfico, desde que se tenha em mente que aqui, quando se fala em possibilidade autobiográfica, ela supõe tão somente a
Da mesma forma, o cinema e o rock foram de grande impacto nos esquemas narrativos adotados por Bayly: a franqueza, o uso constante das marcações de diálogo e a sua capacidade para criar situações verossímeis são algumas de suas virtudes mais notórias como escritor. Bayly é, ainda, um daqueles escritores que poucos pudores tiveram ao assumir o impacto de sua biografia pessoal em seus escritos, confundindo, muitas vezes, os limites entre a ficção e a realidade.

No se lo digas a nadie foi o seu romance de estreia. Desde então, publicou mais nove romances, o que assinala uma profícua carreira literária. ${ }^{3}$ Cabe mencionar também a carreira de apresentador televisivo de Jaime Bayly, uma vez que ela impacta em sua produção literária tanto internamente (em vários romances do autor, o protagonista bissexual cultiva a mesma profissão que o escritor, o que é retratado com requintes de autoironia) quanto externamente (dado que o escritor consegue divulgar massivamente sua obra graças ao reconhecimento que tem, perante o público leitor, como el niño terrible de la televisión peruana). Todos os programas televisivos que conduziu tinham o formato de programa de entrevistas, e Bayly assumia a persona de um entrevistador com humor ácido e irônico, resvalando muitas vezes para o sarcasmo deliberado. Entre eles, merecem destaque 1990 en América (1990), ¿Qué hay de nuevo? (1991), La noche es virgen (1997) e El francoatirador (2001-2006), produzidos por emissoras de televisão peruanas; os programas Tendencias (2006) e Bayly desde Miami (2006) foram produzidos, respectivamente, na Argentina e nos Estados Unidos.

Organizado em três partes, o romance de Bayly conta a história do jovem Joaquín Camino, filho da alta burguesia da capital peruana, desde a descoberta de sua sexualidade, ainda na infância, até a completa constituição de uma identidade homossexual, na idade adulta. As recordações de uma dolorosa e traumática infância vivida por Joaquín continuam a "ecoar" na vida adulta do jovem limenho. Tanto o rechaço por parte da família, depois que o protagonista assume publicamente sua condição homossexual, quanto as mais diversas reverberações dos discursos heteronormativos reproduzidos por instituições como a lgreja, a Escola e a moral da família patriarcal são problematizados nessa trajetória. Ainda que o romance seja uma narrativa heterodiegética ${ }^{4} a$ postular o distanciamento entre a voz narrativa 5 "anônima", que articula os fatos apresentados, e o ponto de vista de Joaquín, a focalização cumpre o papel de dar profundidade ao impacto do discurso homofóbico dirigido ao protagonista, uma vez que o focalizador dominante do romance está associado com o olhar de Joaquín, em especial no que diz respeito à problemática do "assumir-se" homossexual perante 
sobreposição de narrador protagonista, mas não de autor: em outras palavras, uma autobiografia ficcional configura, também, uma narrativa autodiegética).

${ }^{5}$ Quando utilizo "narrador", estou referindo-me à identidade de quem narra os acontecimentos de determinado texto narrativo; já quando utilizo o termo "voz narrativa", o que busco evidenciar é a materialidade linguística do discurso do narrador, pensado como um constructo de linguagem e materializado nas estruturas formais presentes no romance. Apoio-me aqui nas reflexões teóricas de Mieke Bal (1997) e Genette ([s.d.]) com a intenção de deixar explícito que as interpretações construídas através desse método analítico baseiam-se na materialidade linguística do discurso narrativo. ${ }^{6}$ Bal (1997, p. 142) define desta maneira a noção de focalização: "Gostaria de me referir às relações entre os elementos apresentados e a visão através da qual eles são apresentados [em uma narrativa] com o termo focalização. A focalização é, pois, a relação entre a visão [que narra] e aquilo que é 'visto' ou 'percebido' [pela percepção do narrador]". Uma reflexão bastante pertinente sobre o campo dos estudos narratológicos e a crítica literária queer é apresentada por Anselmo Peres ALÓS, 2010 p. $834-864$. os pais em uma sociedade tão conservadora quanto a peruana.

Jaime Bayly utiliza a presumida impessoalidade de uma narrativa heterodiegética na qual uma voz supostamente neutra articula os eventos apresentados. Cabe perguntar, contudo: a voz narrativa que conduz No se lo digas a nadie é realmente impessoal, isto é, isenta de juízos e de acumpliciamentos com relação aos fatos apresentados? Há a possibilidade de se narrar algo a partir de um ponto de vista neutro e não comprometido? Não seria a "impessoalidade" de um narrador heterodiegético, e a neutralidade de uma suposta "terceira pessoa", uma artimanha textual? Não estaria essa voz "impessoal" articulando, a partir da focalização, ${ }^{6}$ uma série de posturas judicativas com relação aos eventos narrados?

Os problemas que Joaquín enfrenta por ser um sujeito de sexualidade desviante surgem já na primeira infância. Enquanto o pai reage com asco e violência à possibilidade de que o filho seja um maricón (isto é, um "viado"), sua mãe, Maricucha, vê a homossexualidade do filho como uma condenável transgressão aos preceitos morais e religiosos de La Obra (i. e., a Opus Dei, uma das fações mais conservadoras da Igreja Católica). Em contrapartida, outras figuras adultas importantes para o jovem Joaquín encontramse envolvidas em vivências marginais, ou mesmo clandestinas, de suas sexualidades. É o caso dos monitores de acampamento da Opus Dei, os quais molestam garotos por ocasião dos retiros de férias, ou das aventuras extraconjugais vividas por seu pai, Luis Felipe, nos bordéis e nas viagens a Miami. Na segunda parte do romance, é apresentada a juventude de Joaquín Camino, suas angústias e a trajetória que leva à constituição de sua própria identidade sexual. Cabe destacar como pontos principais dessa trajetória o affair vivido com Gonzalo, namorado de Rocío, uma de suas melhores amigas, ou la vida loca compartilhada com o colega de faculdade Alfonso, ou ainda, a viagem a Madrid com Juan Ignácio, o qual não mede esforços para sufocar seus próprios impulsos homossexuais. Finalmente, na última parte do romance, tomam lugar a autoafirmação da identidade sexual perante a família, a busca por um companheiro e a desconfortável situação diaspórica vivida no eixo Miami-Lima. A voz narrativa sofre diferentes modulações, de acordo com esses três recortes temporais, de maneira que se possa perceber o impacto das instâncias heteronormativas sobre o protagonista na infância, na adolescência e na idade adulta. Isso evidencia, em termos de narratologia, o fato de que a focalização dominante é dada pelo protagonista, a despeito da voz narrativa supostamente heterodiegética: 
${ }^{7}$ ALÓS, 2010, p. 848-849.

${ }^{8}$ BAYLY, 2003, p. 17, grifos nossos

\begin{abstract}
A voz que narra não pode ser confundida com a consciência que focaliza, pois, enquanto no plano textual este narrador que se declina na primeira pessoa será sempre um narrador interno, a focalização não necessariamente será interna: ela pode oscilar entre interna e externa à medida que o focalizador delegue a focalização para outros personagens, através do discurso direto. $\mathrm{O}$ que se quer aqui explicitar é que a perspectiva do focalizador não é necessariamente a mesma do narrador, mesmo quando este narrador é um narrador-protagonista. ${ }^{?}$
\end{abstract}

Nos capítulos que compõem a primeira parte, diferentes discursos institucionais regulam a "verdade" do corpo de Joaquín. Ao ser transferido para o Colégio Markham, Camino faz amizade com Jorge Bermúdez, seu colega de classe. Este lhe propõe uma "brincadeira" que consiste em que Joaquín seja escravo de Jorge e lhe obedeça em tudo. A brincadeira parece inocente e graciosa, e Joaquín imediatamente concorda em participar. Como primeira ordem da "brincadeira", Joaquín deve pegar a borracha no bolso de Jorge. No entanto, ele percebe rapidamente que não há nenhuma borracha no bolso de Jorge ao tocar no pênis do colega:

- Não tem borracha nenhuma - disse [Joaquín], e retirou sua mão bruscamente.

- Claro que há - disse Jorge, sorrindo -. Acabas de tocá-lo.

- Isso não é uma borracha.

- Toque-o novamente, escravo.

Outra vez, Joaquín enfiou a mão no bolso de Jorge.

- Agora brinque com a minha borracha, escravo disse Jorge.

Joaquín acariciou o sexo de Jorge. Ele sabia muito bem que não estava tocando uma borracha. ${ }^{8}$

Para que o narrador tenha conhecimento de que Joaquín manipulava os genitais de Jorge deliberadamente, sabendo que se tratavam dos genitais e não da presumida borracha escolar, é necessário que esteja articulado um processo de focalização interna. Poderia ainda ser dito que o narrador tem acesso à maneira através da qual Joaquín percebe os eventos narrados. Isso cria uma cumplicidade entre a organização dos eventos enunciados pela voz narrativa e a maneira pela qual Joaquín os percebe. Assim como ele não vê nada de errado ou condenável em brincar com os genitais de Jorge, o narrador também não manifesta qualquer tipo de juízo condenável desse fato.

Ainda dentro do acordo dessa "brincadeira" de senhor e escravo, Jorge ordena a Joaquín que esvazie os pneus do carro do inspetor Moulbright, responsável pelo controle

346 Estudos Feministas, Florianópolis, 21 (1): 343-370, janeiro-abril/2013 
9 Utilizo aqui a noção de aparelho ideológico tal qual formulada por Louis Althusser em Ideologia e aparelhos ideológicos do Estado (1974).

${ }^{10}$ BAYLY, 2003, p. 32.

11 BAYLY, 2003, p. 33

${ }^{12}$ BAYLY, 2003, p. 33.

${ }^{13}$ A noção de heteronormatividade dá conta de um dispositivo social de regulação no qual a premissa básica é a de que a base das relações no espaço público é a presumida heterossexualidade dos cidadãos. O termo foi criado por Michael Warner (1991), em um dos textos fundadores da teoria queer. O conceito retoma a ideia de heterossexualidade compulsória apresentada por Adrienne Rich (1980). Cathy J. Cohen (2005, p. 24), por sua vez, define heteronormatividade como o conjunto de práticas e de instituições "que legitimam e privilegiam a heterossexualidade e relacionamentos heterossexuais como fundamentais $e$ 'naturais' dentro da sociedade".

${ }^{14}$ Conferir, a respeito do funcionamento das premissas heteronormativas no aparato das instituições escolares, o artigo "Gênero, epistemologia e performatividade: estratégias pedagógicas de subversão" (ALÓS, 2011, p. 421-429). ${ }^{15}$ BAYLY, 2003, p. 33. disciplinar dos alunos e que em diversas oportunidades já havia aplicado "corretivos" (golpes de régua nas palmas das mãos) em Jorge. Joaquín acaba sendo pego, e ambos os colegas acabam na sala de Moulbright, de maneira a esclarecer quem foi o responsável pelo que se passou. Diante das ameaças, Jorge Bermúdez não hesita e atribui a culpa a Joaquín, que, para proteger seu amigo, assume a responsabilidade pelo ato. Não satisfeito com isso e para garantir sua saída completamente isento de culpa do caso dos pneus, Jorge delata Joaquín a Moulbright por mariconería (o equivalente em português vernáculo seria o termo viadagem). Conhecedor do princípio heteronormativo cultivado pelo aparelho ideológico escolar, ${ }^{9}$ Jorge consegue assim sair ileso da confusão ao levantar um problema muito mais grave: os comportamentos "imorais" e "pecaminosos" de Joaquín:

- Acontece que [Joaquín] Camino é um viado, senhor Moulbright - disse Jorge.

- Moulbright sorriu, como se houvessem dado uma boa notícia.

- Ah, mesmo? - disse -. Que história é essa?

- [Joaquín] Camino várias vezes tentou me tocar na aula - disse Jorge. ${ }^{10}$

Moulbright dirige-se então a Joaquín Camino, perguntando-lhe se a acusação feita por Jorge é verdadeira: "você tem mesmo este tipo de degeneração?"," ao que responde Camino: "é verdade que eu toquei em [Jorge], senhor Moulbright, mas foi porque ele me pediu isso", ${ }^{2}$ Bermúdez protesta que isso não é verdade, Moulbright lhe dá crédito e Joaquín é punido. Importa salientar aqui o papel da escola no policiamento das sexualidades, bem como a simultânea resistência manifesta pelos alunos. $O$ fato de conhecer o funcionamento heteronormativo ${ }^{13}$ do aparelho escolar não apenas permite que Jorge Bermúdez subverta essa lógica ao praticar jogos sexuais com o colega, como também lhe garante um "abono" para fugir do controle institucional ${ }^{14}$ ao lançar mão da acusação contra Joaquín Camino.

A maquinaria escolar, todavia, permite manipulações de poder mais perversas que o jogo de acusação realizado por Jorge Bermúdez ao longo do romance. Moulbright libera Jorge, mas retém Joaquín em sua sala com a intenção de Ihe aplicar uma disciplina "personalizada": "- Os atos de viadagem são castigados severamente neste colégio continuou Moulbright -. Não há pior falta que um aluno possa cometer do que demonstrar degenerações homossexuais". ${ }^{15}$ Ao mesmo tempo que afirma, como portavoz da instituição escolar, a abjeção com relação às práticas homossexuais, Moulbright utiliza sua posição de 
${ }^{16}$ BAYLY, 2003, p. 34.

\footnotetext{
${ }^{17}$ Robert RUZ, 2003, p. 22.
}

poder com relação a Joaquín Camino. Em troca de seu silêncio com relação à "viadagem" delatada por Jorge Bermúdez, o inspetor Moulbright obriga Joaquín a prestarIhe favores sexuais. Ao mesmo tempo que se masturba, o inspetor de disciplina aplica palmadas nas nádegas de Joaquín: "ele havia aberto a bragueta. Estava masturbandose. Joaquín lhe deu as costas. Moulbright continuou aplicando-lhe palmadas no traseiro. Nem bem terminou, disse a Joaquín que já podia ir-se embora".16

Duas questões importantes devem aqui ser assinaladas. A primeira delas diz respeito à focalização: a narração dos eventos, de maneira econômica e direta, reflete a percepção de Joaquín, na medida em que não implica nenhum juízo acerca do comportamento hipócrita de Moulbright, o qual fica a cargo do leitor. A segunda relacionase com uma constante que se repetirá ao longo do romance: o fato de que as relações eróticas entre homens, mesmo que socialmente censuradas e proscritas, são mostradas como algo do cotidiano, sendo até mesmo desejadas, ainda que não reconhecidas. À medida que tais relações são negadas, silenciadas e, ao mesmo tempo, banalizadas, impossibilitase que se lhes atribua algum significado. É desse mecanismo social, que contraditória e simultaneamente cultiva e condena as relações eróticas entre homens, que se explica o título do livro: não há problemas em que um homem expresse o seu carinho (ou a sua libido) por outro homem, contanto que no se lo digas a nadie (não conte a ninguém).

Uma vez que o romance se passa na capital peruana, em plena década de 90 do século $X X$, e o protagonista pertence à alta burguesia urbana, cabe perguntar: há realmente a necessidade de se viver a homossexualidade na clandestinidade? Não haveria uma rede social - algo como uma subcultura gay - que possibilitasse outras maneiras menos dolorosas de se negociarem as vivências homossexuais na esfera pública, na sociedade limenha? Um fator importante para o estabelecimento das doble vidas (isto é, das "vidas duplas") entre os jovens da elite limenha é dado pela leitura que Robert Ruz faz ao refletir sobre o impacto da obra de Jaime Bayly na sociedade peruana. De acordo com a interpretação de Ruz para el baylyboom,

Uma leitura do texto de Bayly demanda uma sensibilidade para a estruturação econômica das relações homossexuais, assim como para o fato de que, em Lima, as famílias têm a tendência de reter simultaneamente as funções econômica e psicológica (é lugar-comum para os homens solteiros viver na casa dos pais) e que os poucos lugares de socialização gay disponíveis na cidade são extremamente caros para a maioria dos jovens. ${ }^{17}$ 
${ }^{18}$ BAYLY, 2003, p. 94.

${ }^{19} \mathrm{~A}$ noção de uma masculinidade hegemônica, cunhada e reelaborada por Robert Connel (1995 1997 e 1998), é importante para os estudos de gênero, na medida em que visibiliza a compreensão de que há uma maneira hegemônica de se viver a masculinidade, mas também há maneiras subalternizadas, em função de seu maior ou menor potencial para subverter a matriz heteronormativa. Em oposição à masculinidade hegemônica, pode-se pensar, por exemplo, em uma masculinidade indígena, em uma masculinidade negra, em uma masculinidade homossexual ou mesmo em uma masculinidade vivida pelas mulheres, como é o caso, por exemplo, das drag kings.
Ao se observar a dinâmica dos relacionamentos mantidos por Joaquín com outros homens, os quais mantêm suas práticas homossexuais na clandestinidade, ficam evidentes os motivos pelos quais esses relacionamentos estão fadados ao fracasso. Diferentemente de Joaquín, que encara positivamente sua condição sexual e não a vê como algo que o emascule, para os outros personagens o fato de se levar publicamente uma vida homossexual equivale à perda do status social de cidadão correto, de "pessoa de bem". A descoberta da homossexualidade por parte de seus pais, ao final da primeira parte do romance, marca uma importante mudança tanto no plano da história quanto no arranjo narrador/focalizador, uma vez que é aí onde Joaquín é interpelado por uma identidade declinada na orientação sexual. O evento que desencadeia essas mudanças ocorre em uma noite de verão, quando Joaquín sai de sua cama e deita-se com seu irmão mais novo. Repentinamente, depois de tocar o corpo de seu irmão, Joaquín abre os olhos, depara-se com o quadro da Virgem Maria na parede e retorna para sua cama. Seu irmão, Fernando, conta o ocorrido para Maricucha, o que desperta a ira tanto dela quanto de Luis Felipe:

- Asqueroso - gritou Maricucha, e deu uma bofetada em Joaquín [...]

- Um filho viado! - murmurou Luis Felipe, fazendo um gesto de desprezo. - Preferiria ter um filho retardado, caralho! ${ }^{18}$

Depois de ser espancado pelo pai, Joaquín rouba uma das joias da mãe e foge de casa. A fuga marca uma importante reviravolta para o protagonista, já que percebe não ser possível a sua permanência em um núcleo familiar patriarcal, dada a sua orientação sexual e a ojeriza que esta desperta tanto em sua mãe quanto em seu pai. Enquanto o pai é o representante da masculinidade hegemônica ${ }^{19}$ (branca, heterossexual e economicamente privilegiada), a qual se sustenta em bases masculinistas e homofóbicas, Maricucha, com sua dedicação à ala feminina da Opus Dei, é a porta-voz da moral religiosa, que relaciona o par opositivo abstinência/concupiscência com o par virtude/ pecado. No momento em que decide fugir de casa, Joaquín realiza, dessa maneira, um ato simbólico de deslocamento rumo ao umbral e ao limiar do socialmente inteligível, espaço no qual se tornará possível um gesto de resistência aos regimes heteronormativos sintetizados, de maneira explícita, pelas figuras de Luis Felipe e Maricucha.

A partir da segunda parte do romance, a ênfase é dada nas diferentes tentativas de Joaquín em articular uma relação emocionalmente profunda com outros homens, bem 
${ }^{20}$ BAYLY, 2003, p. 131.

${ }^{21}$ BAYLY, 2003, p. 244. como as negociações que realiza, no campo social, com vistas a constituir e legitimar uma identidade a partir de sua orientação sexual. Merece destaque o papel das doble vidas mantidas por vários dos amantes de Joaquín. A doble vida, isto é, a condução de uma vida heterossexual na esfera pública em paralelo com uma vida homossexual clandestina na esfera privada, estará presente como modus operandi de vários parceiros de Joaquín, tais como Alfonso e Gonzalo. Alfonso é um jovem estudante de Direito da Universidad Católica, mais interessado em festas, cocaína e rock and roll do que nas aulas de teoria jurídica. Expulsos da universidade na mesma ocasião, Joaquín e Alfonso tornam-se amigos e, em seguida, amantes. Ao contrário de Joaquín, Alfonso vê sua adicción por los chicos (vício por rapazes) como uma fase momentânea de sua vida, a ser superada assim que encontrar uma esposa e casar-se. Gonzalo, por sua vez, é o namorado de Rocío, uma das melhores amigas de Joaquín. Gonzalo acaba envolvendose com Joaquín Camino e, em uma noitada regada a álcool e cocaína, trata de seduzi-lo, passando a viver um affair clandestino. Tanto Alfonso quanto Gonzalo mostram-se conformados com as condições heteronormativas impostas pela moralidade e pelos valores da classe social à qual pertencem. Alfonso adota uma postura de "enrustimento" na qual não apenas leva uma vida dupla (marcada por um rol de parceiros sexuais clandestinos), mas também resiste a identificar-se como gay ou homossexual:

- Algum dia abandonarei as drogas e os rapazes, e terei de me casar - disse Alfonso, contemplando lá do alto as luzes da noite limenha.

Joaquín olhou para ele e viu em seu rosto um gesto de resignação.

- Mas enquanto for possível, temos de desfrutar a vida - acrescentou Alfonso. ${ }^{20}$

A postura de Joaquín Camino, aparentemente complacente com os privilégios de pertencer à elite branca em um país cuja maioria é de ascendência indígena, revelase sintomaticamente subversiva quando se estabelece um paralelo com as posturas de Alfonso ou mesmo de Gonzalo. Ao pedir a Gonzalo para que conte a Rocío sobre o affair em que estão envolvidos, ouve como resposta o seguinte: "não sejas babaca, Joaquín, uma garota nunca deve estar inteirada desse tipo de coisa. Essas coisas ficam entre homens". ${ }^{21}$ Como estratégia para asseverar que o narrador apresenta os eventos delegando a focalização ao protagonista Joaquín Camino, solapando a suposta neutralidade da voz narrativa heterodiegética, serão cotejados dois momentos que são, também, bastante signifi- 
22 "A enunciação de um artefato cultural é também o lugar no qual um sujeito se projeta textualmente como significante, como princípio articulador de valores. O sujeito da enunciação, enfim, configurase como articulador de um ideologema [...]: uma função intertextual que pode ser lida a partir de sua materialização nos diferentes níveis da estrutura de cada texto, e que se estende ao longo de seu trajeto dando-lhe as suas coordenadas históricas e sociais" (ALÓS, 2010, p. 859).

${ }^{23} \mathrm{~A}$ homossociabilidade, entendida como sociabilidade entre homens, é diferenciada da homossexualidade por Eve Kosofsky Sedgwick em Between Men: English Literature and Male Homosocial Desire (1985). A homonormatividade, por sua vez, tem um papel importante nos rituais urbanos de violência e imolação simbólica das travestis nos espaços públicos de prostituição. Ver, por exemplo, a discussão proposta por Lisa DUGGAN 2002. cativos para a discussão acerca da subversão do regime heteronormativo no romance: o diálogo travado com Alfonso, no capítulo "Amistades peligrosas" ("Amizades perigosas"), e os eventos narrados no capítulo "Sábado en la noche" ("Sábado à noite"), no qual Joaquín Camino toma parte, juntamente com dois outros amigos, de uma violenta investida homofóbica contra duas travestis em pleno trottoir. Nessas duas passagens do romance, é possível analisar o ideologema ${ }^{22}$ da homossociabilidade como um ponto importante para a estruturação do enredo. Cumpre destacar que esses dois eventos evidenciam a não equivalência entre as categorias homossexualidade e homossociabilidade. Se em "Amistades peligrosas" a homossociabilidade ampara as vivências sexuais clandestinas de Alfonso e Joaquín, em "Sábado en la noche" ela funciona como um princípio catalisador a fomentar investidas de violência homofóbica contra travestis. ${ }^{23}$

Ainda no capítulo "Amistades peligrosas", o longo diálogo travado entre Joaquín e Alfonso mostra-se sintomático do investimento político que o protagonista percebe no outing, isto é, na atitude de "assumir-se", de "sair do armário". Joaquín e Alfonso se conhecem ao serem expulsos da Faculdade de Direito e, a partir daí, passam a se encontrar com frequência para beber, fumar maconha, consumir cocaína e falar mal dos pais e da sociedade limenha, em uma atitude anárquica que questiona a intervenção do poder sobre as vidas pessoais. Em dado momento, confessam que se sentem mutuamente atraídos. Em meio ao frenesi causado pelo uso da maconha e da cocaína, Alfonso decide gastar o dinheiro deixado por seu pai para passar as férias indo com Joaquín para o balneário de Punta Sal. Uma noite, acreditando que não estavam sendo observados, ambos vão para a piscina, onde se beijam e são flagrados por um segurança, sendo em seguida expulsos do hotel por comportamento indecoroso. $O$ diálogo em que os personagens discutem acerca das implicações de se viver a homossexualidade no contexto peruano segue esses acontecimentos e se passa durante a viagem de regresso a Lima:

- Atreveria-te a contar aos teus pais que és homossexual? - perguntou Joaquín, no avião de regresso a Lima.

- Nem pensar, estás louco! Fariam um escândalo do caralho - disse Alfonso.

- Mas se quer bem aos teus pais, deveria ser franco com eles.

- Pelo contrário, é justamente porque os amo que prefiro que nunca saibam. Se eles descobrem, eu os faria muito infelizes.

- Algum dia eles vão descobrir através de alguém, 
${ }^{24}$ BAYLY, 2003, p. 140.

${ }^{25}$ No original em espanhol, os termos equivalentes utilizados pelo autor são maricón e maricas, ademais da variante declinada no feminino, maricona.
Alfonso, e isso será pior, porque vais passar por mentiroso.

- Não creio que descubram, Joaquín. Em Lima há um montão de gente que leva uma vida dupla. É uma questão de saber levar as coisas.

- Mas não te sentirias mais tranquilo se lhes contasse a verdade?

- Não. Neste país há certas coisas das quais não se deve falar, e nossa debilidade pelos homens é uma dessas coisas. No Peru podes ser cocainômano, ladrão ou mulherengo, mas não podes te dar ao luxo de ser uma bicha louca. ${ }^{24}$

No momento em que Alfonso afirma que "No Peru podes ser cocainômano, ladrão ou mulherengo, mas não podes te dar ao luxo de ser uma bicha louca", observa-se a refração da hegemonia dos discursos homofóbicos, os quais negam uma existência social legítima para os sujeitos homossexuais. A própria opção lexical de Alfonso, ao utilizar palavras como "viado" ou "bicha louca", ${ }^{25}$ reforça o fato de que o discurso homofóbico integra o rol dos pressupostos constituintes do script da classe social dominante em Lima, colaborando para a manutenção do mito de uma heterossexualidade "natural" e normativa. A conivência de Alfonso com relação às expectativas advindas de sua classe também está manifesta no momento em que revela seu desejo de, em um futuro próximo, casar-se (possivelmente com uma esposa submissa) e ter filhos, mantendo encontros sexuais fortuitos com outros homens na clandestinidade do adultério. Em contrapartida, para Joaquín é inadmissível a possiblidade de um casamento heterossexual meramente para responder aos anseios de seus pais e ao "pacto heteronormativo" previsto pelas convenções sociais de sua classe:

- Tu não me entendes. Eu não estou contra a homossexualidade. $O$ que te digo é que a pratiques por baixo dos panos, que não faças disso um escândalo, que não fodas com a tua reputação.

- É que não poderia casar apenas para manter minha reputação e para alegrar meus pais, Alfonso. Eu me sentiria um ratazana, um manipulador. Não poderia olhar-me no espelho pelas manhãs.

- O matrimônio tem suas vantagens, homem. Se nunca te casas, vais terminar sozinho, amargurado, como esses velhos sujos que vão ao Haiti a ver se conseguem um desses atores medíocres que passeiam por Miraflores. Pensa: deve ser gostoso chegar à tua casa e que a tua esposa te prepare uma boa comida, que tenhas as tuas camisas passadinhas a ferro, que te corte as unhas e que te passe talco nas bolas, que tuas crianças brinquem contigo e que te façam cagar de tanto rir. Portanto, deixa de demências, Joaquín, 
${ }^{26}$ BAYLY, 2003, p. 140. que a vida familiar é uma distração agradável. Eu, de qualquer jeito, quero ter uns filhotes para ver crescer. ${ }^{26}$

Uma das características desse longo trecho é a utilização do discurso direto. A utilização do discurso direto, sem a mediação do narrador, permite que os valores atribuídos a determinado personagem emerjam a partir de sua própria fala, sem que o narrador comprometa-se como uma consciência implicada nas reverberações ideológicas expressas pelas palavras do personagem. Cabe ressaltar que a articulação do discurso direto não impede que determinada focalização, articulada em um outro momento do romance, permeie os enunciados articulados. Mais especificamente, o que se quer dizer é que a cumplicidade entre o narrador e o protagonista, esboçada na primeira parte do romance, estende-se também para a segunda parte, mesmo que não haja uma interferência direta da voz narrativa. O antecedente da censura homofóbica sofrida pelos dois companheiros no hotel em Punta Sal dinamiza ainda mais os aspectos políticos da postura pró-outing de Joaquín. Para ele, o ato de assumir-se publicamente como homossexual é equivalente a um levante revolucionário, na medida em que a visibilidade homossexual possibilitaria uma mudança nas estruturas sociais heteronormativas:

\footnotetext{
- E quando tens vontade de estar com um homem, o que vais fazer?

- Sair para dar uma volta, trepar com alguém, fazer uma viagem, e pronto. É como quando teu carro começa a dar problema: leva-o à oficina, e lhe fazem o conserto, o lavam e o engraxam, e está terminado, te deixam o carro novinho em folha.

- Parece-me horrível que os homens estejam ai somente para que te façam uma troca de óleo de vez em quando, Alfonso. Eu gostaria de ter um companheiro, e de viver com ele.

- Isso é impossível nesse país, Joqquín. Olha só o que acabou de nos acontecer. Se queres viver com um homem e ter uma vida de casal, terás de abandonar - Peru. O Peru não é a Dinamarca, compadre.

- Eu sei, eu sei, mas se todos somos uns covardes e seguimos enfiados no armário, as coisas nunca vão mudar.

- Eu prefiro ficar tranquilito no armário. Se crês que a tua missão é imolar-te pela causa de umas bichinhas e de uns travestis que estão tomando a sua cervejinha na rua das pizzas, te dou minhas felicitações, tiro o chapéu e te desejo toda a sorte do mundo, mas não me peças que salte contigo ao precipício.

- No fundo te cagas de medo, Alfonso.

- Não é que eu tenha medo, Joaquín. É que não sou um suicida, como tu és. ${ }^{27}$
} 
${ }^{28}$ Judith BUTLER, 1993, p. 309.

Alfonso, a seu turno, considera extremamente improvável que a visibilidade realmente tenha tal potencial para alavancar alguma mudança social. Incomoda a Alfonso o fato de renunciar a seus privilégios de classe ao assumir tal postura enquanto "umas bichinhas e de uns travestis [...] estão tomando a sua cervejinha na rua das pizzas". O argumento final de Alfonso desvela o peso do estigma da homossexualidade: ao afirmar que "não sou um suicida, como tu és", compactua com a lógica heteronormativa que define os corpos dos homens homossexuais como abjetos e não humanos, uma vez que a homossexualidade assumida em público equivale ao suicídio social. O enrustimento de Alfonso - isto é, sua decisão por "ficar tranquilito no armário" manifestaria então uma postura reacionária e antiprodutiva do ponto de vista político? O posicionamento sustentado por Joaquín, com sua defesa da visibilidade homossexual (implicada no coming out of the closet, isto é, no "sair do armário"), seria a proposta mais acertada? Não de todo. Com certeza, a modulação discursiva pró-outing é a dominante do romance, uma vez que a focalização articulada pela voz narrativa privilegia a perspectiva do protagonista Joaquín Camino. Contudo, as ideias de Alfonso permitem uma leitura enviesada da qual é possível extrair outras reflexões complementares às políticas de visibilidade.

Alfonso não mantém sua sexualidade em segredo única e exclusivamente como maneira de manter os privilégios assegurados aos homens heterossexuais em uma sociedade patriarcal e heteronormativa; há também, em suas palavras, uma importante problematização das políticas afirmativas que veem no outing a solução para a discriminação e a violência homofóbicas. A filósofa Judith Butler, ao refletir sobre o funcionamento da dinâmica do closet (ou ainda, da lógica do enrustimento), destaca que

"Assumir-se" sempre depende, em certa extensão, de ser "enrustido"; "sair do armário" ganha o seu significado apenas dentro desta polaridade. Assim, "assumir-se" produz o "enrustimento" reiteradamente, como a própria condição de possibilidade do "assumir-se". Neste caso, o "assumir-se" pode apenas produzir uma nova opacidade; e o "armário" [ou o "enrustimento"] produz a promessa de um discurso que pode, por definição, nunca acontecer. ${ }^{28}$

Ao se analisarem as palavras de Alfonso à luz da afirmação de Judith Butler, é possível pensar nessa "política do armário", da qual Alfonso é adepto, não apenas como uma solução conformista para manter os privilégios da heterossexualidade. Em certa medida, o que Alfonso expressa é um olhar crítico com relação ao outing e às políticas de visibilidade das identidades sexuais, um olhar que não deixa

354 Estudos Feministas, Florianópolis, 21 (1): 343-370, janeiro-abril/2013 
${ }^{29}$ Ademais dos trabalhos de Butler (1993), conferir Toril MOI, 1985; e Sadie PLANT, 1999.

${ }^{30}$ Edward SAID, 1990 e 1995.

${ }^{31}$ Yvonne MAGGIE e Claudia Barcellos REZENDE, 2002.

\begin{abstract}
${ }^{32} \mathrm{As}$ primeiras reflexões feitas nesse sentido, questionando o binarismo que se estabelece entre a homossexualidade assumida e a homossexualidade enrustida, são de autoria de Eve Sedgwick (1985). A produção performativa do enrustimento como consequência residual da confissão pública da identidade homossexual, ademais de ter sido abordada por Judith Butler (1993), é também abordada por Eve Sedgwick (1990).
\end{abstract}

${ }^{33}$ BAYLY, 2003, p. 33 de ter certa parcela de pertinência. Dentro de uma lógica desconstrutiva, em todo binarismo conceitual há o estabelecimento de uma hierarquia na qual o primeiro termo é valorizado em detrimento da desvalorização e da negativização do segundo. Essa noção, cujo nascedouro é a filosofia desconstrutiva de Jacques Derrida, tem pautado as reflexões de diversas correntes contemporâneas do pensamento político e da crítica cultural. Em alguns ramos da teoria feminista, analisa-se a valorização das categorias homem e masculinidade, respectivamente, em oposição às de mulher e feminilidade; ${ }^{29}$ nos estudos pós-coloniais, a oposição entre civilidade e barbarismo vem sendo questionada como um argumento legitimador da violência imperialista do período colonial; ${ }^{30}$ nos estudos de raça, a oposição entre brancos e negros vem sendo considerada como uma construção retórica que legitima a ação opressora dos sujeitos sociais descritos pelo primeiro termo sobre aqueles "outros" descritos pelo segundo, de maneira mais ou menos independente da cor da pele desses sujeitos. ${ }^{31}$

A questão que se coloca a partir da problematização das políticas do outing e da visibilização de uma identidade homossexual não escapa dessa dinâmica. ${ }^{32}$ Ao se classificarem os sujeitos homossexuais em categorias fechadas como "assumidos" (os que estão out of the closef) e "enrustidos" (os que estão in the closef), subordina-se a segunda categoria à primeira. A questão é que a política da afirmação de uma identidade, ao mesmo tempo que pode ser uma postura performativa produtiva em termos de visibilidade política, pode também ter um efeito pernicioso. Se a identidade homossexual "assumida" é produzida através de um ritual performativo, uma vez que é a partir da afirmação "eu sou gay" que se produz a visibilidade, essa afirmação também instaura, como "resto" ou "resíduo", a reafirmação da possibilidade (ou mesmo da necessidade retroativa) de se estar "no armário". No plano textual do romance No se lo digas a nadie, essa dinâmica pode ser percebida através da necessidade reiterada de Joaquín Camino enunciar, repetidas vezes, a sua condição sexual. O primeiro momento no qual ele declara sua homossexualidade se dá quando é interpelado pelo inspetor Moulbright, do Colégio Markham, na ocasião em que é pego esvaziando os pneus do seu automóvel. Jorge Bermúdez acusa seu colega de "viadagem", ao que o inspetor Moulbright pergunta: "você tem esse tipo de degeneração?". Joaquín, diante dessa interpelação, responde: "creio que sim". ${ }^{33}$

A identidade homossexual é produzida, pois, nesse entrecaminho entre a confissão pública e o segredo desvelado. É à luz dessas ideias que merece ser lido o momento no qual Joaquín Camino recebe do pai seu presente 
${ }^{34}$ Termo vulgar e grosseiro utilizado no espanhol coloquial falado no Peru para se referir à vagina.

35 BAYLY, 2003, p. 65

${ }^{36}$ Termo vulgar, mas não necessariamente grosseiro, utilizado no espanhol coloquial falado no Peru para se referir ao pênis. Equivalentes próximos no português falado no Brasil seriam os termos rola e vara, embora esses sejam julgados mais ou menos grosseiros de acordo com a região brasileira.

37 Termo vulgar e grosseiro utilizado no espanhol coloquial falado no Peru para se referir ao pênis.

${ }^{38}$ BAYLY, 2003, p. 64. pelo aniversário de 13 anos. As "casas de encontro" ocupam um espaço no qual a socialização se dá exclusivamente entre homens. Dentro das estruturas do patriarcado, o bordel é o lugar no qual mais evidente fica a objetificação da mulher: as prostitutas são reduzidas à condição de corpos sexuados, objetos do desejo masculino, mercadorias, ou ainda, mero valor de troca entre homens. Decidido a tornar seu filho um homem a qualquer preço, Luis Felipe leva Joaquín a um prostíbulo para que esse perca a virgindade e seja iniciado no mundo dos homens. Ou ainda, de maneira mais esquemática, tal como expresso nas palavras do próprio Luis Felipe, para "comer uma chuchita ${ }^{34}$ gostosa" ${ }^{35}$ pela primeira vez:

- Qual é o teu problema, rapaz? - perguntou ela -. Tu gostas de pichulas? ${ }^{36}$

- Não, não - disse Joaquín, surpreendido - por que pensas isso?

- Não, por nada, paizinho, por nada. Mas se tu gostas de pichulas, ${ }^{37}$ não te preocupes, deixa-te levar pelo instinto. Caso contrário, vais sofrer horrores.

- Obrigado, Flora.

- Se quiseres, volta um outro dia e tentamos de novo, rapazinho. Eu, por carne branca e maciazinha, trabalho de graça.

- Ele sentou-se na cama e colocou os sapatos.

- Imploro-te que não contes nada ao meu pai, pode ser? - disse, amarrando os sapatos - por favor, não conte a ninguém, Flora. ${ }^{38}$

Ironicamente, é no momento em que Luis Felipe leva seu filho para o bordel, um dos espaços mais heteronormativos das sociedades patriarcais, que Joaquín Camino trava contato, pela primeira vez, com alguém que não julga de maneira depreciativa seu desejo por outros garotos. $O$ diálogo com a prostituta Flora abre uma nova possibilidade de valoração para a homossexualidade. Cabe destacar também que a instauração da identidade sexual de Joaquín se dá tanto pela enunciação performativa de sua parte quanto pela interpelação de sua sexualidade através do discurso de Flora. É ela quem nomeia, e com algum traço de positividade, a identidade sexual de Joaquín. A interpelação do jovem por essa identidade marica se estabelece definitivamente ao chegar em casa, quando ele se masturba pensando em um colega de escola e, logo após o gozo, identifica-se, ainda que parcialmente, com Flora:

A primeira coisa que Joaquín fez ao entrar em seu quarto foi tirar a roupa e enfiar-se no chuveiro. Parado embaixo de um jato de água quente, tocou seu sexo, o ensaboou, o fez crescer. Em seguida fechou os olhos e masturbou-se pensando em um garoto do colégio. 
39 BAYLY, 2003, p. 68-69, grifos nossos.

${ }^{40}$ Raymond WILLIAMS, 1977.

${ }^{41}$ BAYLY, 2003, p. 226.
O garoto chamava-se Billy. Era loiro, forte, muito bom nos esportes. Joaquín o havia visto desnudo algumas vezes no vestiário do colégio. Sentindo o jato de água quente nas costas, as pernas relaxadas, o sexo rijo, Joaquín imaginou Billy suado no vestiário, imaginouse baixando suas calças, baixando-lhe o suporte. chupando-o, abaixando a boca para que Billy o penetrasse. Imaginou Billy movendo-se atrás dele, mordendo-Ihe as costas. Sim, paizinho, faz-me coisas gostosas, disse, mordendo-se os lábios. Gozou. Abriu os olhos. Riu-se sozinho, pensando que havia falado como Flora. ${ }^{39}$

Antes de se julgarem apressadamente as vivências clandestinas da homossexualidade, é importante ressaltar o papel da contradição na constituição tanto de Gonzalo e Alfonso quanto do próprio Joaquín Camino. Não se pode perder de vista que la doble vida é a única condição possível de existência social para Camino e Alfonso. O que pode parecer uma postura leviana para os herdeiros das políticas afirmativas pós-Stonewall estadunidenses é, ao mesmo tempo, uma performance relativamente subversiva no contexto das moralidades elitistas de Lima. Jaime Bayly, com seu romance, subverte e questiona o capital cultural heteronormativo das elites peruanas. Ou ainda, pensando nos termos de Raymond Williams, ${ }^{40}$ o romance de Bayly colabora na constituição de novas estruturas de sentimento, interferindo diretamente no campo das negociações simbólicas, as quais impactam a legitimidade social atribuída às subjetividades subalternizadas. A postura de Joaquín, que pode passar desavisadamente por "militante", também encerra suas próprias contradições. O capítulo intitulado "Sábado en la noche" expõe os impasses nos quais Joaquín Camino está imbricado quando questões de gênero, orientação sexual e travestismo estão alinhadas.

Em um sábado modorrento, Joaquín é convidado por Juan Carlos e Gustavo, dois amigos que conheceu em uma festa, a ir até o Centro da cidade tomar algumas cervejas e divertir-se com os três gramas de cocaína que Gustavo conseguira. Completamente entorpecido pela cocaína e pelo álcool, Gustavo conta a Joaquín sobre a noite em que saiu com uma garota e, ao levá-la para a cama, descobriu que se tratava de uma travesti:

- Parecia uma femeazinha - disse Juan Carlos - Por Deus que parecia uma femeazinha.

- Tinha umas tetinhas bem formadinhas - disse Gustavo.

- E como deram-se conta? - perguntou Joaquín. [...]

- Ela queria que eu metesse por trás, e quando tentei meter pela frente, então me dei conta - disse Gustavo. ${ }^{41}$ 
${ }^{42}$ BAYLY, 2003, p. 226.

${ }^{43}$ BAYLY, 2003, p. 226.

${ }^{44}$ BAYLY, 2003, p. 229-230, grifos nossos.

\footnotetext{
${ }^{45}$ Trechos que seguem o discurso direto, seja para identificar a qual personagem pertence uma fala, seja para acrescentar alguma informação não acessível através do diálogo dos personagens.

${ }^{46}$ Os termos no texto original em espanhol são, respectivamente, "cabro", "maricón chuchatumadre", "cabro apestoso".
}

Sob o efeito da cocaína, os três decidem ir até a rua Javier Prado, ponto de trottoir, com vistas a espancar travestis. Joaquín tenta dissuadir os dois amigos, mas sem sucesso: "vamos perder tempo com besteiras - disse Joaquín. Melhor irmos ao Amadeus". ${ }^{42}$ A resposta vem em seguida: "que Amadeus, babaca - disse Juan Carlos - . Foder com a vida desses viados é mais bacana". ${ }^{43}$ Importa aqui sublinhar a articulação entre narração e focalização, bem como a contraditória constituição da subjetividade de Joaquín:

Havia uma mulher atrás de uma árvore.

- Vem aqui, então, - gritou Gustavo [...].

- Segue o teu caminho, narigudo - gritou a mulher [...].

- A quem pensas que vais faltar com o respeito, hein, viadão filho da puta? - gritou Gustavo.

- A ti, ora [...] - gritou a mulher [...].

Gustavo alcançou a mulher que Ihe havia insultado

e a lançou ao chão. Em seguida atirou-se sobre ela e começou a lhe golpear o rosto.

- Morra, viado fedorento - gritou Gustavo.

- Não é viado, é uma mulher - gritou Joaquín.

- É um viado, seu babaca - gritou Gustavo - Chuta-o tu também.

Joaquín chutou a mulher algumas vezes [...].

Em seguida lhe baixaram a calcinha e viram o sexo erguido desse homem vestido de mulher. ${ }^{44}$

Os itálicos na citação anterior se referem à perspectiva de Joaquín (e, por extensão, uma vez que esse ocupa o papel de focalizador, dizem respeito também à perspectiva do narrador), enquanto os itálicos negritados referem-se à perspectiva de Gustavo. Desde o momento em que aborda a vítima, Gustavo sabe que se trata de uma travesti. O narrador, entretanto, uma vez que está acumpliciado com a focalização dada por Joaquín, refere-se à vítima como se essa fosse uma mulher. Isso pode tanto indicar que Joaquín reconhece o gênero performativizado pela travesti como feminino, como também pode sinalizar uma "políitica de redução de riscos" a modalizar a economia de suas ações (se Gustavo ficasse convencido de que se tratava de uma prostituta, talvez desistisse de espancar a travesti). Já que a focalização realizada pelo personagem Gustavo é dissonante daquela adotada pelo focalizador dominante, ela é expressa através do discurso direto, e não pelo discurso do narrador. Nas incisas narrativas, ${ }^{45}$ quando o narrador identifica as falas da travesti na discussão com Gustavo, sempre se refere a ela como "a mulher". Gustavo, por sua vez, utiliza termos depreciativos que marcam o travestilidade e a homossexualidade da vítima: "viado", "viadão filho da puta", "puto fedorento". ${ }^{46}$ Apenas depois que Joaquín aceita participar do 
${ }^{47}$ BAYLY, 2003, p. 66.

${ }^{48}$ BAYLY, 2003, p. 66.
${ }^{49}$ BAL, 1997; Susana LANDA e José ONEGA, 1995; e Susan LANSER, 1986. espancamento, quando tiram as roupas íntimas da travesti para "averiguar" seu "verdadeiro" sexo, é que o narrador refere-se à vítima como um homem travestido: "[e]m seguida Ihe baixaram a calcinha e viram o sexo erguido desse homem vestido de mulher".

O fator-chave a despertar a violência de Gustavo contra a travesti é a homofobia, expressa no orgulho da autodenominação "exterminador de viados" (matacabros, no texto original do romance). Joaquín participa desse ritual de violência simbólica contra a sua vontade? Pode-se argumentar que o fator a justificar a participação de Joaquín no espancamento da travesti não é a homossexualidade, mas sim a misoginia que Ihe foi "imposta" através dos conselhos de seu pai acerca de como portar-se com as mulheres: "e acredite: todas [as mulheres] são putas, só que algumas já sabem, e outras ainda não". ${ }^{47}$ Luis Felipe, na mesma ocasião, diz ao filho: "nunca dê atenção quando uma mulher te diz não. Lembre-se que todas são comíveis". ${ }^{48}$ Mesmo estando no umbral do status quo, posto que sua orientação sexual the exclui do privilégio delineado nos termos de uma masculinidade heteronormativa, isso não impede Joaquín de adotar posturas misóginas. As relações sociais envolvendo as premissas de gênero e de orientação sexual são mais complexas do que podem parecer à primeira vista. Assim como não há uma contiguidade causal entre orientação sexual, identidade de gênero e sexo anatômico, também não há, no campo das afinidades políticas, uma premissa sobredeterminante que faça com que os homens homossexuais sejam necessariamente solidários às agendas políticas do feminismo.

Esse tipo de contraponto ideológico é justamente o que empresta à obra de Bayly sua força crítica, desmantelando mitos sociais com relação à sociedade peruana. Sua linguagem coloquial e o uso constante dos diálogos, longe de diminuírem o valor da obra - como afirmam alguns de seus críticos -, apontam para o fato de que é no cotidiano microscópico das relações sociais que se instaura o violento confronto entre sexualidades hegemônicas e subalternizadas. O narrador, de uma suposta neutralidade por situar-se fora do enredo de No se lo digas a nadie, ao ter sua voz combinada com a focalização dominante, dada pelo protagonista Joaquín Camino, põe em xeque sua isenção ao acumpliciarse de maneira visível com o locus do protagonista da narrativa.

Sob o ponto de vista das teorias narratológicas clássicas, ${ }^{49}$ o romance de Jaime Bayly articula um narrador extradiegético que somente ao final do romance se mostrará "acumpliciado" com a perspectiva de Joaquín Camino. Contudo, ainda que tal acumpliciamento somente possa 
${ }^{50}$ Utilizo aqui o termo no sentido formulado por Michel Foucault em $A$ arqueologia do saber (2000). ser explicitado no final da narrativa, é possível, ao longo do romance, observar a sintonia entre o narrador extradiegético e o protagonista Joaquín Camino através da maneira pela qual são apresentados os outros personagens, bem como suas crenças e valores. Merecem destaque, nesse sentido, os personagens Luis Felipe e Maricucha, genitores do protagonista.

Luis Felipe é descrito como um homem que busca compulsivamente o reconhecimento público através da ostentação do poder financeiro e da masculinidade. Maricucha, em contrapartida, é apresentada como uma mulher frustrada no casamento e que se entrega completamente aos preceitos morais da Opus Dei. Esses dois personagens podem ser considerados como os "porta-vozes" de dois grandes discursos da sexualidade: o da heteronormatividade masculinista, por parte do pai, e o que relaciona o sexo ao pecado e à devassidão, ao qual sua mãe está afiliada. Podem-se considerar esses dois personagens como a síntese das duas grandes forças sociais contra as quais Joaquín terá de se debater em sua busca pela legitimidade de sua orientação sexual. Nesses termos, o espaço privado do lar paterno não deve ser entendido em oposição ao espaço público; o espaço domiciliar, em No se lo digas a nadie, não é apenas o cárcere privado ao qual estão destinados os cidadãos de segunda categoria (ou mesmo aqueles alijados de toda e qualquer cidadania), em oposição ao âmbito do espaço público, no qual os sujeitos em posse de plena e reconhecida cidadania debatem suas ideias. No romance de Jaime Bayly, a casa dos pais é um microcosmo, a antessala da ágora, e nesse microcosmo se reproduzem, em escala reduzida, as formações discursivas ${ }^{51}$ que oprimem Joaquín e que o oprimirão por ocasião de sua entrada no espaço público.

Esse "ingresso" no mundo público, no qual se dão as relações sociais, é reiteradamente adiado, já que para Joaquín não resta outro lugar que o umbral da ágora, um espaço de liminaridade, fora do espaço social legitimado pelas regras heteronormativas. A escolha pelo espaço domiciliar como célula-máter da sociedade e, ao mesmo tempo, como microcosmo no qual estão contidas as mesmas forças sociais que operam no macrocosmo social possibilita compreender os discursos de Luis Felipe e Maricucha de maneira amplificada. Isto é, Luis Felipe e Maricucha não falam meramente como sujeitos de suas próprias vozes e cosmovisões, mas como os porta-vozes de instituições marcadamente ideológicas e de sabida eficiência no controle dos corpos e das subjetividades sexuais: de um lado, os valores do patriarcado branco das elites peruanas, representados pelo pai; de outro, os valores sacralizados 
pela ala mais conservadora da Igreja Católica, a Opus Dei, representados pela mãe.

Uma vez que para Luis Felipe o exercício da masculinidade hegemônica é o pressuposto para o exercício do poder, a homossexualidade do filho implica o aceite de uma simbólica emasculação, a qual o torna inapto para a cidadania plena e o livre exercício do legado de autoridade representado pelo pai. Mais do que a orientação sexual do filho, o que perturba Luis Felipe é a confissão pública da homossexualidade, pois, quando vivida clandestinamente, tal condição não é impeditiva para que um filho seja sucessor do legado paterno, de acordo com o imaginário nacional peruano expresso no romance de Bayly. Dado que os interesses de classe de Luis Felipe estão legitimados por um ideário patriarcalista no qual se destaca a valorização da masculinidade hegemônica e da heterossexualidade, Joaquín rompe com as bases fundamentais do poder patriarcal ao declarar-se homossexual, condição proscrita no âmbito público. É nesse sentido que a homossexualidade torna-se a condição da liminaridade social de Joaquín, o qual se encontra condenado a uma cidadania de segunda categoria na homofóbica e patriarcal sociedade peruana. Maricucha, ao cumprir o script de mulher devota a rezar permanentemente, garantindo assim o perdão dos pecados e a salvação de todas as almas da família patriarcal, encarna o ideal de uma representação marianista do feminino, bastante forte não apenas no Peru, mas em praticamente todas as culturas nacionais latino-americanas. O marianismo consiste em se tomar o ícone cristão da Virgem Maria, bem como todos os valores nessa imagem concatenados (pureza, santidade, submissão e temência a Deus) como modelo arquetípico de identidade feminina a ser seguido pelas mulheres "de bem". O marianismo tem um importante papel na constituição identitária de Maricucha: ao ver toda manifestação ou interesse sexual como pecado, essa se coloca como a patrulheira da virtude dos membros de sua família, quase que uma procuradora de Deus a negociar a salvação das almas do esposo e dos filhos.

Ao se interpretar a liminaridade das escolhas pessoais de Joaquín e seu embate com os valores representados pelos pais, sua busca por experiências sexuais $(e$, mais tarde, a fuga de casa e a drogadição) deve ser lida como metáforas oposicionistas, ou ainda, como a maneira simbólica de afastar-se do patriarcalismo racista e elitista do pai, bem como da falaciosa moral cristã, denunciada nos abusos que os padres e os seminaristas cometem com os jovens sob seus cuidados. Enquanto para Luis Felipe a "viadagem" do filho é vista como falta de caráter e de masculinidade, para Maricucha ela implica pecado. Aliás, para ela, a 
${ }^{51}$ BAYLY, 2003, p. 71.

${ }^{52}$ A noção de masculinidade hegemônica a que se faz menção foi cunhada por Robert Connel (1995). Dele também é a ideia de que a resistência a modelar o corpo masculino de acordo com modelos hegemônicos de masculinidade heterossexual configura-se como uma postura subversiva. Para ver mais a esse respeito, conferir CONNEL, 1997 e 1998.

${ }^{53}$ BAYLY, 2003, p. 18

${ }^{54}$ BAYLY, 2003, p. 18.

${ }^{55}$ BAYLY, 2003, p. 12. possibilidade do pecado é a grande ameaça que ronda o filho, para o qual Maricucha tem uma aspiração secreta: o sacerdócio. Cumpre assinalar também que Maricucha não é feliz em seu casamento com Luis Felipe, a despeito das condições financeiras e do status social que goza: "às vezes não vejo a hora em que o Senhor me leve para o céu. [...] A vida terrena é desilusão atrás de desilusão atrás de desilusão" ${ }^{34}$ Assim, seu apego à fé e à "vida celestial" que a aguarda depois da sua morte fornece também algo de amparo às desditas de sua vida.

Como o acólito da masculinidade hegemônica, Luis Felipe incita em Joaquín posturas de desconfiança e violência com relação ao outro. É necessário estar sempre alerta e disposto a provar a própria hombridade publicamente, seja em confrontos físicos com outros colegas de escola, seja na objetificação e no abuso das mulheres. Nesse sentido, a masculinidade heterossexual e hegemônica é inscrita no corpo a partir de um árduo processo de caráter performativo. Há que se aprender a ser homem. A necessidade de um corpo forte e embrutecido, forjado nas brigas com outros garotos e nos exercícios físicos (tais como a natação e o futebol), se dá na medida em que isso legitima e legibiliza a identidade heterossexual masculina no próprio corpo. Na esteira desse argumento, pode-se interpretar a constituição física de Joaquín (magro, delicado, pouco dado à prática de esportes) como uma postura de resistência à inscrição desse modelo de masculinidade, representado pelo pai, em seu próprio corpo. ${ }^{52}$ Logo que Joaquín muda de escola, no princípio do romance, esse o interpela a ostentar uma masculinidade de índole violenta como valor positivo perante os seus outros colegas. As evasivas desculpas do filho, ao argumentar, de maneira tímida, que "é que eu não sou bom de briga, papai", ${ }^{53}$ fomentam a postura homofóbica de Luis Felipe, que vê no falsete da voz do filho os primeiros indícios de efeminamento: "O quê? Fala grosso, caralho! A nós, homens, a voz sai dos culhões. Tu, por tua vez, parece que falas pelo cu, garoto". ${ }^{4}$

Ao revés das projeções de Luis Felipe, que deseja ver no filho um prolongamento de si mesmo e do poder patriarcal que representa, as aspirações de Maricucha são as de que seu filho torne-se um casto sacerdote: "eu sei o que tu queres, mamãe. Tu queres é que eu seja sacerdote", ${ }^{55}$ declara o jovem Joaquín, mostrando-se conhecedor do destino que lhe é auspiciado pela mãe. O exercício de uma sexualidade fora do padrão heterossexual mostra-se como um desafio não apenas aos papéis de gênero assumidos e performativizados pelo pai e pela mãe, mas se estende como crítica a instituições sociais que, mais além da heteronormatividade e da lógica de uma sociedade gendrada, tais como a lgreja, o classismo 


\begin{abstract}
${ }^{57}$ Termo ofensivo utilizado no espanhol coloquial falado no Peru para se referir a um descendente indígena de classe subalterna.
\end{abstract}

${ }^{58}$ BAYLY, 2003, p. 92 e o patriarcado branco, regulam e normativizam as práticas dos jovens das classes abastadas.

Ainda que o narrador não denuncie nem a si mesmo, nem a Joaquín Camino como antirracistas, a descrição das arbitrariedades regidas pelos imperativos do imperialismo branco em Lima permite ler, através da crueza de algumas descrições, uma modalização discursiva avessa ao racismo institucionalizado. Discorda-se aqui da asseveração enunciada por alguns críticos, como Robert Ruz, ao afirmar que a posição privilegiada de Jaime Bayly em seu ofício de escritor - o pertencimento à elite econômica e racial peruana - torná-lo-ia insensível a problemas graves dentro da sociedade limenha, tais como a discriminação dos indígenas pela minoria branca:

Poderia ser argumentado que o texto de Bayly preocupa-se pouco com as questões de classe, ou de raça, ou de política sexual. Em termos de classe, Bayly escreve a partir de uma posição privilegiada e muito específica, e os membros desta mesma classe em Lima já possuem considerável liberdade em termos de possibilidades alternativas de se viver a sexualidade em virtude de seu poder econômico. No que tange às questões de raça, Bayly perpetua a tendência da cultura de massa peruana, tal qual feito pela publicidade e pela televisão, na qual a pele branca e os cabelos claros são contínua e reiteradamente elogiados como belos. ${ }^{56}$

A afirmação feita sobre o tratamento dado por Bayly à questão da raça em seu romance parece ser um pouco mais delicada e complexa do que a afirmação de Ruz faz supor. Ao se levar em consideração uma postura política que aposta na paródia e na ironia, há pelo menos dois momentos em que a questão do racismo é apresentada. Uma delas é a cena na qual Luis Felipe, retornando de uma caçada com Joaquín em "El Aguerrido", atropela um cholo ${ }^{57}$ que parecia alcoolizado:

- Joaquín virou-se, assustado. Não pode ver ao sujeito que acabaram de atropelar. Tido estava demasiadamente escuro.

- Melhor pararmos, papai - disse.

- Estás louco? - disse Luis Felipe -. Eu é que não vou recolher este cholo bêbado. Além disso, já deve estar morto. Teríamos de o levar ao hospital e estaríamos fodidos ao ter de explicar à família o que aconteceu. Tratariam de arrancar-me dinheiro, esses sacanas. Que se foda por ser imbecil esse cholo babaca. ${ }^{58}$

Mesmo com os protestos de Joaquín, o qual insiste para que o pai dê assistência ao indígena atropelado, ele se nega a descer do carro. A referência ao racismo manifesto 
${ }^{59}$ BAYLY, 2003, p. 13.

${ }^{60}$ BAYLY, 2003, p. 14, grifos nossos.

na fala de Luis Felipe e as tentativas do jovem de demovê-lo a auxiliar o homem atropelado indicam uma postura crítica com relação ao racismo do pai. Muito mais do que o receio por complicações com a lei é o racismo que comanda a atitude de Luis Felipe. Já nas primeiras páginas do romance, ele faz a seguinte declaração: "deveriam fuzilar em massa a todos esses índios e lançar os corpos ao rio Rímac, caralho disse -. Assim andaria para a frente o Peru", ${ }^{59}$ declara Luis Felipe.

O racismo emerge nas mais diversas esferas sociais. Logo no início do romance, esse aparece instalado no pequeno diálogo que se estabelece entre Jorge Bermúdez e Joaquín Camino: até mesmo um reles diálogo sobre futebol termina por mostrar-se como argumentação para enunciados racistas:

- Tu gostas de futebol - perguntou Joaquín.

- Mais ou menos - disse Jorge.

- Torces para qual time?

- Para o Universidad Católica, ora. Todos nós, brancos, torcemos pelo Universidad. .0

Não há intervenções por parte do narrador, ou mesmo monólogos do protagonista ou de outros personagens, dedicadas à problematização da questão racial no romance. Todavia, isso não significa dizer que a questão não está abordada neste texto literário. Essas cenas, explícitas ao denunciarem a existência do racismo na sociedade limenha, por si só, já indicam um olhar crítico sobre a questão, uma vez que o contexto no qual tais descrições aparecem é o de uma crítica à hipocrisia das elites peruanas. Na medida em que a focalização é dada por um branco também subalternizado (por conta de sua sexualidade), não será exagero ler, nas descrições dos comportamentos racistas do pai, uma crítica a essas posturas racistas.

Outro ponto a abonar a leitura de um posicionamento antirracista de Joaquín está no fato de que o próprio Joaquín é vitimado pelo hate speech etnofóbico, quando, em Miami, é flagrado roubando gravatas em uma loja de departamentos. Ao ser pego por um dos seguranças, que observara a tentativa de roubo pelo circuito interno de televisão, o jovem peruano ouve insultos como "another fucking Latin American" ("mais um filho da puta latino-americano") ${ }^{61}$ - como se todos os furtos a lojas de departamentos em Miami fossem realizados por latino-americanos - e "for a Latin American, you have pretty good taste"62 (para um latino-americano, você até que tem relativo bom gosto) - como se os latino-americanos, além de estarem condenados à "cleptomania", estivessem também condenados ao mau gosto. Se por um lado Miami pode parecer mais acolhedora do que Lima para um jovem gay

364 Estudos Feministas, Florianópolis, 21(1): 343-370, janeiro-abril/2013 
${ }^{63}$ BAYLY, 2003, p. 298-299.

da elite peruana, dado que as consequências do machismo patriarcal são menores do que em Lima, por outro Joaquín será sempre another fucking Latin American, mesmo sendo branco e filho das classes abastadas. Ironicamente, quando está em Miami, Joaquín sofre na pele as consequências do racismo e da etnofobia que são características dos membros de sua própria classe social em seu país natal.

Não é apenas no advento do furto das gravatas que se explicita a inter-relação entre discurso ufanista e racismo. É surpreendente a clareza dos princípios racistas e patriarcalistas subjacentes no ufanismo de Luis Felipe. Em uma conversa com Joaquín, Luis Felipe expõe claramente sua visão de como as coisas devem ser para que se alcancem a ordem e o desenvolvimento no Peru:

- Bom, como eu ia dizendo, que é o problema do Peru? A coisa está muito clara, filho, meridianamente clara. O problema é que os brancos e os cholos odeiam-se mutuamente, mas também se necessitam mutuamente. Vamos ver se tu me entendes: nós brancos não gostamos dos cholos, falamos mal dos cholos. afastamo-nos dos cholos, estás acompanhando? - Ahãm.

- Mas o problema é que nós brancos não podemos viver sem os cholos, Joaquín. Por que então, quem vai trabalhar para nós? Quem são nossos trabalhadores, nossa mão de obra? Ora, tem que ser os cholos. E quem serão nossas empregadas, nossas cozinheiras, nossas lavadeiras? Têm de ser as cholas, ora. ${ }^{63}$

Em sua ufanista declaração, em nome da manutenção das diferenças sociais no Peru, Luis Felipe manifesta pleno conhecimento do modus socialis operandi da maquinaria patriarcal que, a partir da divisão social do trabalho por gênero e por raça, perpetua a hegemonia branca, elitista, masculinista e heterossexual. As palavras de Luis Felipe evidenciam também que a hegemonia dessa elite não é mero resultado das "diferenças naturais" entre homens e mulheres ou entre indígenas e brancos, mas que tal estado de coisas é fruto de um longo processo de expropriação e subalternização dos não brancos e dos não homens. Se as mulheres (entendidas como não homens) são corpos a serem domesticados, desfrutados e colonizados pelos sujeitos masculinos, os homossexuais (também "não homens" dentro da lógica patriarcal) devem ser excluídos e rechaçados. A legitimação de práticas eróticas que não sejam heterossexuais ameaça esse arranjo social, uma vez que admitir a existência dos homossexuais (como sujeitos sociais legítimos) coloca em risco a naturalização das relações sociais tal qual efetivada pelo patriarcado. Ao final do romance, Joaquín decide abandonar seus pais e fixar residência em Miami 
como modo de fugir das patrulhas ideológicas de Lima. Consegue, finalmente, estabelecer uma relação estável com Peter, um estadunidense que trabalha como carregador de malas em um hotel em Miami. O descaso de Joaquín para com a sua identidade nacional é sintomático de um malestar geral que angustia os jovens peruanos no final do século XX: "para a minha geração, o patriotismo é uma piada de mau gosto", 64 desabafa.

O ceticismo de Joaquín estende-se mais além das questões de pertença nacional. Em seu monólogo final, a articulação entre voz narrativa heterodiegética e focalização interna dá-se explicitamente. Neste momento, concretiza-se textualmente a superposição entre a perspectiva do narrador, o qual se mantém isento na maior parte do romance, e a perspectiva de Joaquín Camino. O narrador "cita" deliberadamente os pensamentos de Joaquín, os quais, dedicados à sua mãe, tomam a forma de uma oração profana na qual o personagem pede a compreensão de Maricucha:

Agora Joaquím também estava chorando. Chorava porque tinha vontade de dizer à sua mãe "tens de entender que sou homossexual, mamãe, que sempre fui homossexual, provavelmente quando estava na tua barriga já estava fazendo-me homossexual, mas não é por isso que sou uma pessoa má, não é por isso que deixo de te amar, se ao menos pudesses entender que não sou viado apenas para te enfrentar, para me vingar de ti, que sou homossexual e que essa é a minha natureza e porque eu não a posso mudar, e por favor, não vejas a minha homossexualidade como um castigo de Deus, não a vejas como algo terrível, porque ela não é, olhe-a mais como uma oportunidade para entender melhor as pessoas, para entender que as coisas não são sempre brancas ou negras, compreenda, por favor, mamãe, que ao fim e ao cabo a única coisa importante é que eu também te amo, te amo muitíssimo, adoro teus caprichos e tuas carolices, mas não posso deixar de ser quem eu sou, e tenho de aprender a amar-me e respeitar-me, e a não trair a minha orientação sexual, e a dizer às pessoas que sou homossexual sem que por isso fique com as faces vermelhas, e sem que eu me sinta sujo, porco, uma pessoa má, porque não o sou, sou teu filho e te amo, sou homossexual e sou uma boa pessoa, e se Deus existe, ele te contará algum dia por que lhe passou pela cabeça de me fazer homossexual" ${ }^{65}$

A heteronormatividade é denunciada como um regime político que legitima, ao mesmo tempo, a normativização do desejo heterossexual e a divisão binária dos gêneros. Da mesma maneira, é lícito afirmar que os três romances em questão posicionam-se, em maior ou menor grau, contra a 
${ }^{60}$ Ángel MORENO SÁNCHEZ e José Ignácio PICHARDO GALÁN, 2006 p. 152.

${ }^{67}$ BAYLY, 2003, p. 297. homonormatividade, isto é, uma maneira elitista, normativizante e neoliberal de se vivenciar a homossexualidade. De acordo com Ángel Moreno Sánchez e José Ignácio Pichardo Galán,

A homonormatividade configura-se através da troca de significado das práticas sexuais das pessoas que as realizam, assim como os contextos sociais e culturais nos quais se dão tais práticas. Estas trocas de significado baseiam-se comumente na recriação hiperbólica que, a partir da hegemonia heterossexual, é realizada dessas práticas quando levadas a cabo por homossexuais. Assegura-se assim a hegemonia heterossexual e se constitui a homonormatividade, hipervisibilizando e selecionando certos comportamentos realizados por um grupo específico de pessoas qualificadas como homossexuais. O pensamento homonormativo associa, a partir da hegemonia heterossexista, os comportamentos homossexuais a uma classe social e a um estilo de vida previamente determinado. ${ }^{66}$

Em No se lo digas a nadie, fica muito evidente o alinhamento de diferentes posturas fóbicas e discriminatórias (como o racismo, a misoginia, a homofobia e o classismo) em torno de um interesse comum: a manutenção dos privilégios sociais de uma pequena parcela da população. Sob a rubrica da "verdadeira cidadania peruana" e do "progresso da nação", usurpa-se das mulheres, dos indígenas, dos homossexuais e das classes economicamente menos favorecidas o direito de participação política plena no imaginário nacional. Cabe salientar que os ideologemas da exclusão estão a serviço da manutenção dos privilégios detidos pelos setores hegemônicos no que diz respeito à raça, à classe social, às práticas sexuais e aos papéis de gênero. Seguindo tal raciocínio, a postura cínica de Joaquín com relação aos espasmos de patriotismo de Luis Felipe revela uma postura de resistência e de subversão. Seu pai, pelo contrário, mesmo sendo vítima de ameaças telefônicas realizadas pelos "terroristas" indígenas, não abre mão de residir em sua terra natal: "ninguém vai me colocar para fora do meu país [...] Que partam os mariquinhas. Eu fico". ${ }^{67}$ Maricucha, por sua vez, aceita de maneira resignada 0 destino que o script social limenho the reservara: o de submissa e virtuosa guardiã do lar e da família. Mesmo ela estando em uma posição subalternizada na hierarquia de gênero, manifesta sua cumplicidade com o status quo e o seu orgulho de ser peruana:

- Não fale assim do teu país, da tua gente - disse Maricucha -. Falar mal do teu país é como falar mal da tua família.

- Mamãe, não sejas de mau gosto, por favor - disse 
${ }^{68}$ BAYLY, 2003, p. 327.

${ }^{69}$ Monique WITTIG, 2002, p. 21 32. ele, rindo-se -. O patriotismo é a pior de todas as demonstrações de mau gosto.

- Eu não sei por que meus filhos me saíam tão antiperuanos - murmurou ela, e suspirou.

- Eu não sou antiperuano, mamãe, mas me incomoda viver no Peru porque é um país meio selvagem - disse Joaquín. ${ }^{68}$

Importa observar aqui a lógica perversa da mentalidade hétero. ${ }^{69}$ Mesmo Joaquín não consegue operacionalizar seu raciocínio crítico fora de uma lógica do ou isto ou aquilo: para criticar a opressão sofrida pelos homossexuais em seu país, ele operacionaliza um juízo que envolve o par opositivo civilização versus barbárie, tomando por "civilização" o contexto estadunidense gay friendly de Miami. Entretanto, ao reduzir diferenças culturais a uma questão de civilidade ou selvageria, Joaquín aciona a mesma lógica binária que subordina a homossexualidade à heterossexualidade que está na raiz do pensamento homofóbico. A posição privilegiada do personagem Joaquín nas hierarquias sociais da sociedade peruana com relação à classe e à raça, em contraposição com sua posição subalterna nos regimes hegemônicos de masculinidade e expressão sexual, evidencia, em última análise, que a reprodução de estereótipos e das desigualdades, muitas vezes, recebe a contribuição dos próprios sujeitos marginalizados, os quais reproduzem a lógica da exclusão.

\section{Referências}

ALÓS, Anselmo Peres. "Narrativas da sexualidade: pressupostos para uma poética queer". Revista Estudos Feministas, Florianópolis: UFSC, v. 18, n. 3, p. 837-864, 2010. Disponível em: <http://www.scielo.br/pdf/ref/v18n3/v18n3a11.pdf>. Acesso em: 10 abr. 2012.

. "Gênero, epistemologia e performatividade: estratégias pedagógicas de subversão". Revista Estudos Feministas, Florianópolis: UFSC, v. 19, n. 2, p. 421-449, 2011. Disponível em: <http://www.scielo.br/pdf/ref/v19n2/ v19n2a07.pdf > . Acesso em: 9 ago. 2011.

ALTHUSSER, Louis. Ideologia e aparelhos ideológicos do Estado. Tradução de J. J. Moura Ramos. Lisboa: Presença/ Martins Fontes, 1974.

BAL, Mieke. Narratology. 2. ed. Buffalo: The University of Toronto Press, 1997.

BAYLY, Jaime. No se lo digas a nadie. Barcelona: Planeta, 1994. 1995.

. Fue ayer y no me acuerdo. Barcelona: Seix Barral, . Los últimos días de 'La Prensa'. Barcelona: Planeta, 1996. 
. La noche es virgen. Barcelona: Anagrama, 1999. Los amigos que perdi. Barcelona: Anagrama, 2000. . Aquí no hay poesia. Barcelona: Anagrama, 2001. . La mujer de mi hermano. Barcelona: Planeta, 2002. No se lo digas a nadie. Barcelona: Seix Barral, 2003.

(Colección Pocket Books). El huracán lleva tu nombre. Barcelona: Planeta, 2004. Y de repente, un ángel. Barcelona: Planeta, 2005. . El canalla sentimental. Barcelona: Planeta, 2008. . El cojo y el loco. Barcelona: Alfaguara, 2009. Morirás mañana. Barcelona: Alfaguara, 2010.

. El misterio de Alma Rossi: morrirás mañana II. Barcelona: Alfaguara, 2011.

. Escupiran sobre mi tumba: morirás mañana III. Barcelona: Alfaguara, 2012.

BUTLER, Judith. Bodies that Matter. London: Routledge, 1993.

COHEN, Cathy J. "Punks, Bulldaggers, and Welfare Queen: The Radical Potential of Queer Politics?" In: JOHNSON, Patrick; HENDERSON, Mae G. (Ed.). Black Queer Studies: A Critical Anthology. Duke: Duke University Press, 2005. p. 21-51.

CONNEL, Robert. Masculinities. Berkeley: The University of Califórnia Press, 1995.

. "La organización sexual de la masculinidade". In: VALDÉZ, Teresa; OLAVARRÍA, José (Ed.). Masculinidades: poder y crisis. Santiago de Chile: Ediciones de Mujeres, 1997. p. 31-48.

"El imperialismo y el cuerpo de los hombres". In: VALDÉZ, Teresa; OLAVARRÍA, José (Ed.). Masculinidades y equidad de género en América Latina. Santiago de Chile: FLACSO, 1998. p. 76-89.

DUGGAN, Lisa. "The New Homonormativity: The Sexual Politics of Neoliberalism." In: CASTRONOVO, Russ; NELSON, Dana D. (Ed.). Materializing Democracy: Toward a Revitalized Cultural Politics. Duke: Duke UP, 2002. p. 175-194.

FOUCAULT, Michel. A arqueologia do saber. 6. ed. Rio de Janeiro: Forense Universitária, 2000.

GENETTE, Gérard. Discurso da narrativa. Tradução de Francine C. Martins. Lisboa: Vega, [s.d.].

LANDA, Susana; ONEGA, José (Ed.). Narratology. Longman: London/New York: 1995.

LANSER, Susan. The Narrative Act: Point of View in Prose Fiction. Princeton: Princeton University Press, 1986.

MAGGIE, Yvonne; REZENDE, Claudia Barcellos (Org.). Raça como retórica: a construção da diferença. Rio de Janeiro: Civilização Brasileira, 2002.

MOI, Toril. Sexual/Textual Politics: Feminist Literary Theory. London/New York: Methuen, 1985.

MORENO SÁNCHEZ, Ángel; PICHARDO GALÁN, Juan Ignácio. "Homonormatividad y existéncia sexual". Revista de 
Antropología Iberoamericana, v. 1, n. 1, p. 143-156, enero/feb. 2006.

PAREDES, Martín; ZAVALETA, Ricardo. "Permiso para escribir". Quehacer, Lima, n. 134, enero/feb. 2002. Disponível em: <http://www.desco.org.pe/publicaciones/QH/QH/ qh134mp.htm >. Acesso em: 10 dez. 2006.

PLANT, Sadie. Mulher digital: o feminino e as novas tecnologias. Rio de Janeiro: Rosa dos Tempos, 1999.

$\mathrm{RICH}$, Adrienne. "Compulsory Heterosexuality and Lesbian Existence." Signs: Journal of Women in Culture and Society, v. I, n. 5, p. 631-660, 1980. Disponível em: <http:// www.jstor.org/stable/31 73834>. Acesso em: 1 jan. 2012.

RUZ, Robert. "Queer Theory and Peruvian Narrative of The 1990's: The Mass Cultural Phenomenom of Jaime Bayly." Journal of Latin American Cultural Studies, v. 12, n. 1, p. 19-36, 2003.

SAID, Edward W. Orientalismo. São Paulo: Companhia das Letras, 1990.

Cultura e imperialismo. São Paulo: Companhia das Letras, 1995.

SEDGWICK, Eve Kosofsky. Between Men: English Literature and Male Homosocial Desire. New York: Columbia University Press, 1985.

The Epistemlogy of The Closet. Berkeley: The University of California Press, 1990.

WARNER, Michael. "Introduction: Fear of a Queer Planet." Social Text, n. 29, p. 3-17, 1991.

WILLIAMS, Raymond. Marxism and Literature. Oxford: Oxford University Press, 1977.

WITTIG, Monique. "The Straight Mind." In: The Straight Mind and Other Essays. Boston: Beacon Press, 2002. p. 21-32.

[Recebido em 3 de outubro de 2011 reapresentado em 10 de abril de 2012 e aceito para publicação em 18 de maio de 2012]

\begin{abstract}
Not to Tell Anybody or to Tell Everybody? Collapses of Masculinity in No se lo digas a nadie

Abstract: Taking narratology and queer studies as theoretical assumptions, what is made here is a critical reading of No se lo digas a nadie [Don't Tell Anyone], Peruvian novel written by Jaime Bayly (first published in 1994) in which is questioned the heteronormative that rules the Peruvian society. For that, we emphasize the subversive potential of a place of literary utterance marked by difference and resistance to the disposals of sexual identities regulation.

Keywords: Comparative Literature; Peruvian Novel; No se lo digas a nadie; Jaime Bayly.
\end{abstract}

